certain region of relative vapor pressure is shown. It is proposed to interpret the transformation of desorption isotherms with the growth of the $\mathrm{C} / \mathrm{S}$ model «ruffle» (Maxwell's principle). Such a model representation combines individual nontrivial experimental effects into a certain fundamental regularity.

Thus, the involvement of a topological approach opens up new possibilities in modeling real situations with sudden catastrophic rearrangements of regimes in developing dynamic systems.

\title{
References:
}

1. Николис Г., Пригожин И. Самоорганизация в неравновесных системах. М. : Мир, 1979. 512 с.

2. Трофимова Л.Е., Урьев Н.Б. Моделирование процессов структурообразования дисперсных систем и материалов. Одесса : Астропринт, 2011. $36 \mathrm{c.}$

3. Гленсдорф П., Пригожин И. Термодинамическая теория структуры, устойчивости и флуктуаций. М.: Мир, 1973. 280 с.

4. Урьев Н.Б. Высококонцентрированные дисперсные системы и материалы. М. : Техполиграфцентр, 2018. 407 с.

DOI https://doi.org/10.30525/978-9934-588-79-2-2.32

\section{ОБГРУНТУВАННЯ РІВНІВ ОБСЛУГОВУВАННЯ ПРИ ЕКСПЛУАТАЦІЙНОМУ УТРИМАННІ АВТОМОБІЛЬНИХ ДОРІГ}

\author{
Харченко А. М. \\ кандидат технічних наук, доиент, \\ доцент кафедри транспортного будівництва та управління майном \\ Національного транспортного університету \\ м. Київ, Украӥна
}

Пріоритетними питаннями щодо експлуатаційного утримання автомобільних доріг в Україні є обгрунтування раціональних рівнів їх обслуговування, що впливатимуть на:

- підвищення безпеки дорожнього руху;

- збереження складових автомобільних доріг; 
- забезпечення виконання вимог користувачів автомобільних доріг;

- збереження навколишнього середовища.

У зв'язку з впровадженням довгострокових контрактів про утримання автомобільних доріг за принципом забезпечення їх експлуатаційного стану відповідно до нормативно-правових актів, норм та стандартів, що регламентовано статею 6, абзацу 2 Закону України «Про автомобільні дороги» [1], виникла необхідність в обгрунтуванні рівнів облуговування як складової нормативно-технічного документу, який здатен утворити нормативну основу впровадження довгострокових контрактів відповідно до потреб національної економіки й суспільства, користувачів доріг, сучасного світового рівня наукових досягнень та світового досвіду експлуатації автомобільних доріг.

Чинні нормативні документи: ДСТУ 3587-97 «Безпека дорожнього руху. Автомобільні дороги, вулиці та залізничні переїзди. Вимоги до експлуатаційного стану», П-Г.1-218-113:2009 «Технічні правила ремонту та утримання автомобільних доріг загального користування України» та П Г.1-218-118:2005 «Сдині правила зимового утримання автомобільних доріг» за повнотою охоплення дефектів елементів складових автомобільних доріг недостатні для належного впровадження довгострокових контрактів згідно Закону України «Про автомобільні дороги» і не містять техніко-економічних обгрунтувань кількісних параметрів вимог з усунення дефектів [2].

Довгострокові контракти з експлуатаційного утримання автомобільних доріг на основі забезпечення кінцевих експлуатаційних показників [2] є новим явищем в дорожньому господарстві України. Їх економічне обгрунтування $є$ складним науковим завданням, яке вимагає розв'язання багатьох теоретико-методологічних завдань, зокрема, окрім інших:

- розроблення моделей і алгоритмів обгрунтування параметрів рівнів обслуговування;

- обгрунтування специфікацій рівнів обслуговування елементів доріг за допомогою розроблених моделей і методик.

В Україні перші роботи, присвячені довгостроковим контрактам, були виконані 2015 pр. в Національному транспортному університеті [2-3]. Були розроблені Методичні рекомендації з їх застосування [1], а також створена Інформаційно-аналітична система управління довгостроковими контрактами на основі рівнів обслуговування доріг (ІАСУ-ДККП) з відповідним програмним забезпечення, примірна база даних рівнів обслуговування, науковим колективом НТУ також було 
розроблено два державних стандарти щодо обгрунтування рівнів обслуговування автомобільних доріг при їх експлуатаційному утриманні. Перспективами наукових досліджень $є$ практична апробація наведених розробок та їх вдосконалення з урахуванням потреб галузі та сучасного світового рівня наукових досягнень.

\title{
Література:
}

1. МР В.3.2-02070915-844:2014 Методичні рекомендації з управління станом автомобільних доріг на основі довгострокових контрактів з поточного дрібного ремонту та утримання доріг за показником рівня їх обслуговування. Київ, 2011.35 с.

2. Розробити методику та інформаційно-аналітичну систему управління станом автомобільних доріг на основі довгострокових контрактів з поточного дрібного ремонту та утримання доріг за показником рівня їх обслуговування. Звіт про науково-дослідну роботу № 35-13. № державної реєстрації 0113U001972. Київ, 2013. 135 с.

3. Виконати аналіз та розробити вимоги до усунення дефектів елементів доріг при реалізації довгострокових контрактів 3 поточного дрібного ремонту та експлуатаційного утримання автомобільних доріг загального користування. Звіт про науково-дослідну роботу № 49-15. № державної реєстрації 0115U001651. Київ, 2013. 217 с.

DOI https://doi.org/10.30525/978-9934-588-79-2-2.33

\section{ПРОБЛЕМАТИКА ЗАСТОСУВАННЯ КОНСТРУКЦІЙ УКРІПЛЕННЯ УКОСІВ ЗЕМЛЯНОГО ПОЛОТНА АВТОМОБІЛЬНИХ ДОРІГ}

\author{
Чечуга О. C. \\ кандидат технічних наук, дочент, \\ доиент кафедри транспортного будівництва та управління майном \\ Національного транспортного університету \\ м. Київ, Украӥна
}

Головний ворог земляного полотна - вода. Стійкість зволоженого грунту знижується, тому в залежності від місцевих умов потрібно виконати заходи щодо забезпечення стабільності земляного полотна. До їх числа відносяться:

- регулювання поверхневого стоку; 